\title{
PENGARUH LATIHAN STANDING BROAD JUMP TERHADAP LOMPAT JAUH GAYA JONGKOK SISWA SMP NEGERI 2 LAHAT
}

\author{
Mirza Awali \\ Universitas PGRI Palembang \\ mirza.awali@gmail.com
}

\begin{abstract}
Abstrak
Masalah dalam penelitian ini adalah Apakah terdapat pengaruh latihan standing broad jump terhadap hasil lompat jauh gaya jongkok pada siswa putra kelas VIII SMP Negeri 2 Lahat. Penelitian ini bertujuanuntuk mengetahui pengaruh latihan standing broad jump terhadap hasil lompat jauh gaya jongkok pada siswa putra kelas VIII SMP Negeri 2 Lahat. Jenis penelitian ini adalah penelitian eksperimen, dengan menggunakan metode one group pretest-posttest desain. Populasi dalam penelitian ini adalah adalah seluruh siswa putra kelas VIII SMP Negeri 2 Lahat dengan jumlah 20 siswa. Sedangkan sampel dalam penelitian ini seluruh siswa putra yang berjumlah 20 orang. Teknik penentuan sampel dalam penelitian ini menggunakan teknik sampling jenuh. Teknik pengumpulan data menggunakan metode tes lompat jauh gaya jongkok. Teknik analisis data menggunakan rumus uji-t. Berdasarkan hasil penelitian yang telah dilakukan terhadap siswa kelas VIII SMP Negeri 2 Lahat, tentang pengaruh latihan standing broad jump terhadap hasil belajar lompat jauh gaya jongkok sebanyak 20 siswa (sampel) diperoleh hasil pada uji normalitas data bahwa semua data berdistribusi normal, baik pre-test maupun post-test. Kemudian pada uji hipotesis diperoleh hasil $t_{\text {hitung }}$ adalah 7,40 sedangkan $t_{\text {tabel }}$ adalah 1,73 Sudah menjadi ketentuan bahwa apabila $t_{\text {hitung }}>t_{\text {tabel }}$, maka $H_{a}$ (Hipotesis diterima) dan sebaliknya apabila $t_{\text {hitung }}<t_{\text {tabel }}, H_{o}$ (Hipotesis ditolak), maka dapat disimpulkan bahwa latihan standing broad jump berpengaruh terhadap hasil lompat jauh gaya jongkok pada siswa kelas VIII SMP Negeri 2 Lahat.

Kata kunci: Standing Broad Jump, Lompat Jauh Gaya Jongkok, Siswa
\end{abstract}

\section{THE INFLUENCE OF BROAD JUMP STANDING EXERCISE TOWARD A LONG STYLE JUMP STUDENTS OF SMP 2 LAHAT}

\begin{abstract}
The problem in this study is whether there is an influence of standing broad jump training on the results of squat-style long jump on the male students of class VIII of SMP Negeri 2 Lahat. This study aims to determine the effect of standing broad jump exercises on the results of squat-style long jump on male students of class VIII of SMP Negeri 2 Lahat. This type of research is experimental research, using the one group pretest-posttest design method. The population in this study were all male students of class VIII of SMP Negeri 2 Lahat with a total of 20 students. While the samples in this study were all male students, amounting to 20 people. The sampling technique in this study uses the saturation sampling technique. Data collection techniques using the squat-style long jump test method. Data analysis techniques using the t-test formula. Based on the results of research conducted on eighth grade students of SMP Negeri 2 Lahat, about the effect of standing broad jump training on squat style long jump learning outcomes of 20 students (samples) the results obtained in the data normality test that all data are normally distributed, both pre-test and post-test. Then the hypothesis test results obtained t_count is 7.40 while t _table is 1.73 It is a condition that if $t_{-}$count $>t$ _table, then Ha (Hypothesis accepted) and vice versa if t_count <t_table, Ho (Hypothesis rejected), it can be concluded that standing broad jump exercise affects the squat style long jump results in class VIII students of SMP Negeri 2 Lahat.
\end{abstract}

Keywords: Standing Broad Jump, Squat Jump Long Jump, Students

188 | Copyright@HON 
Correspondenceauthor: Mirza Awali, Universitas PGRI Palembang, Indonesia. E-Mail: mirza.awali@gmail.com

\section{(c) (i) (2)}

Jurnal HalamanOlahraga Nusantara licensed under a Creative Commons Attribution-ShareAlike 4.0 International License.

\section{PENDAHULUAN}

Pendidikan bertujuan menyiapkan pribadi dalam keseimbangan, kesatuan. Organis, harmoni, dinamis, guna mencapai tujuan hidup kemanusian.Landasan filosofis pendidikan sesungguhnya merupakan suatu sistem gagasan tentang pendidikan dan dedukasi atau dijabarkan dari suatu sistem gagasan filsafat umum yang dianjurkan oleh suatu aliran filsafat tertentu.Pendidikan adalah upaya mengembangkan potensi-potensi manusiawi peserta didik baik potensi fisik potensi cipta, rasa, maupun karsanya, agar potensi itu menjadi nyata dan dapat berfungsi dalam perjalanan hidupnya serta olahraga tidak berdasar pada selera saja (Lengkana, 2018). Dasar pendidikan adalah cita-cita kemanusiaan universal.

Pendidikan pada sekolah juga mencangkup olahraga yang diantaranya bola besar, bola kecil, dan atletik yang pada tujuannya menselaraskan lari dan lompat (Sugarwanto \& Okilanda, 2020). Olahraga merupakan kegiatan yang umum dilakukan manusia, olahraga sekarang sudah mendapatkan perhatian penuh terutama untuk meningkatkan kualitas manusia Indonesia yang sehat jasmani dan rohani, disiplin dan bertanggung jawab. Seperti yang sering kita dengar yaitu meningkatkan dan memelihara kesehatan dan kebugaran jasmani, prestasi, membina persatuan dan kesatuan bangsa, memperkokoh ketahanan nasional serta harkat, martabat dan kehormatan bangsa.

Olahraga disaat ini telah menjadi kebutuhan bagi masyarakat untuk menjaga serta meningkatkan kondisi fisik tubuh agar tetap bersemangat dalam melakukan kegiatan sehari-hari serta berkemampuan untuk berprestasi dengan baik. Hal ini sesuai dengan tujuan khusus dari aktifitas berolahraga, kegiatan olahraga di Indonesia tidak hanya sekedar untuk kesegaran jasmani atau rekreasi saja, namun harus berfikir kearah peningkatan prestasi untuk dapat mengharumkan nama bangsa dan negara digelanggang nasional ataupun internasional. 
Atletik merupakan olahraga dari berbagai macam penggabungan gerakan, seperti olehraga jalan, lari, lompat, dan melempar (Rahmani, 2014). Tingkat sekolah dan perguruan tinggi, olahraga atletik seringkali digunakan sebagai pengujian kesehatan jasmani seseorang siswa, baik dari segi kekuatan, kecepatan, kelenturan daya tahan, koordinasi.

Atletik adalah olahraga yang tumbuh dan berkembang bersamaan dengan gerakan alami manusia.Berjalan, berlari, melompat, dan melempar adalah bagian yang tidak terpisahkan dari sejarah panjang kehidupan manusia. Cabang olahraga atletik merupakan nomor yang wajib untuk dilombakan pada setiap kegiatan multi event, baik secara nasional maupun internasional. Salah satu nomor dalam atletik adalah jalan, lari, lompat dan lempar, lompat dalam atletik terdiri dari lompat jauh lompat tinggi lompat jangkit dan lompat galah (Sukirno \& Pratama, 2018). Lompat jauh dibagi menjadi tiga gaya lompatan yaitu, gaya jongkok (tuck style), gaya gantung (hang style), dan gaya berjalan di udara (walking in the air) (Kurniawan, 2012). Pada penelitian ini peneliti tertarik untuk meneliti lompat jauh gaya jongkok yang akan diteliti pada sampel di SMP Negeri 2 Lahat.

Olahraga lompat jauh menuntut gerakan disaat sang atlet melakukan lompatan setelah diawali dengan berlari sehingga menghasilkan lompatan yang jauh (Kurnia, 2018). Pemenangnya ditentukan dari seberapa jauh sang atlet melompat di kolam pasir sebagai media pengukurnya. Lompat jauh adalah suatu bentuk gerakan melompat yang diawali dengan gerakan horizontal dan diubah ke gerakan vertical dengan jalan melakukan tolakan pada satu kaki yang terkuat untuk memperoleh jarak sejauh-jauhnya (Wiarto, 2013). Lompat jauh adalah gerak lompatan yang dilakukan di lintasan dengan bak pasir yang digunakan untuk mendarat yang ukurannya yang sudah ditentukan. Lompat jauh merupakan gerakan menolakan kaki dan mengangkat kaki ke atas untuk melakukan pendaratan sejauh-jauhnya (Husdarta, 2009).

Perkembangan olahraga khususnya lompat jauh pada cabang olahraga atletik, tidak lagi mencapai prestasi gemilang, hal ini diakibatkan kurangnya pembinaan yang baik.Bila atlet atau siswa ingin berprestasi lebih tinggi lagi haruslah diadakan pembinaan yang baik melalui metode yang cocok untuk 190 | Copyright@HON 
peningkatan prestasi, misalnya melalui pembinaan kondisi fisik yang optimal. Seperti Unsur poweryang merupakan komponen utama dalam kinerja olahragawan. Seperti pada seorang pelompat jauh. Karena unsur terpenting pada seorang pelompat jauh adalah kecepatan (speed) yang berkaitan dengan awalan dan daya ledak (explosive) yang berkaitang dengan tolakan pada papan tolak untuk mendapatkan kecepatan vertical (Wiarto, 2013).

Menurut Suherman (2001) kategori baik dalam lompat jauh adalah minimal 7,50 meter. Jika melihat acuan pendapat ahli diatas sangat terlihat harapan pencapaian hasil lompatan lompat jauh pada siswa, akan tetapi bila melihat pencapaian ternyata belum ada sama sekali prestasi yang didapat oleh siswa SMP Negeri 2 Lahat, pada cabang olahraga lompat jauh baik di evant daerah bahkan di evant nasional, Berdasarkan hasil observasi yang peneliti peroleh dari SMP Negeri 2 Lahat kelas VIII bahwa masih banyak siswa yang belum bisa melakukan teknik dasar lompat jauh. Hal ini terlihat pada saat difase awalan siswa masih banyak yang tidak fokus, tidak memiliki percaya diri, langkah pada saat lari masih lebar, pada fase tolakan dimulai dari pelan ke cepat, pada fase di udara tidak sesuai dengan teknik dasar, dan pada saat fase mendarat bagian kaki masih terlihat kaku yang seharusnya mengeper, masih banyak siswa yang mendarat tetapi kedua tangan jatuh dibelakang tubuh.

\section{METODE}

Metode penelitian adalah metode yang menjelaskan tentang metode apa yang digunakan dalam penelitian yang digunakan dalam penelitian ini adalah “One Group Pre test Post test Desain” (Winarno, 2007). Dalam rancangan ini digunakan satu kelompok subjek. Pertama-tama dilakukan pengukuran, lalu dikenakan perlakuan untuk jangka waktu tertentu, kemudian dilakukan pengukuran untuk kedua kalinya.

Tabel 1. Desain Penelitian One Group Pre Test-Post Test

\begin{tabular}{ccc}
\hline Pretest & Treatment & Posttest \\
\hline $\mathrm{T}_{1}$ & $\mathrm{X}$ & $\mathrm{T}_{2}$ \\
\hline
\end{tabular}

\section{1 | Copyright@HON}


Penelitian ini dilaksanakan di SMP Negeri 2 Lahat pada bulan April 2019 yang beralamat J1. Letnan Amir Hamzah No. 1, Ps. Baru, Kec. Lahat, Kabupaten Lahat, Sumatera Selatan 31461.Populasi adalah wilayah generalisasi yang terdari atas obyek/subyek yang mempunyai kualitas dan karakteristik tertentu yang ditetapkan oleh penelitian untuk dipelajari dan kemudian ditarik kesimpulannya (Sugiyono, 2008). Populasi dalam penelitian ini adalah seluruh siswa putra kelas VIII SMP Negeri 2 Lahat dengan jumlah 20 siswa. Sampel adalah sebagian atau wakil populasi yang di teliti. jadi sampel disini adalah sebagian dari jumlah dari karakteristik yang dimiliki populasi sebagai wakil populasi yang diteliti (Arikunto, 2010). Pengambilan sampel ini dimaksudkan untuk memperoleh keterangan mengenai objek penelitian,dan mampu memberikan gambaran dan populasi.Pengambilan sampel dalam penelitian ini menggunakan teknik sampling jenuh. Sampling jenuh adalah teknik penentuan sampel bila semua anggota populasi digunakan sebagai sampel (Arikunto, 2010). Maka sampel dalam penelitian ini berjumlah 20 siswa.

Teknik pengumpulan data merupakan langkah yang paling utama dalam penelitian, karena tujuan utama dari penelitian adalah mendapatkan data. Tanpa mengetahui teknik pengumpulan data, maka peneliti tidak akan mendapatkan data yang memenuhi standar data yang ditetapkan (Sugiyono, 2008). Untuk mengumpulkan data penelitian yang mana sasaran dari penelitian ini adalah siswa putra kelas VIII di SMP Negeri 2 Lahat sebanyak 20 orang dan untuk mendapatkan data yang akurat dalam penelitian ini, maka peneliti mengumpulkan data dengan melakukan tes lompat jauh gaya jongkok melalui latihan standing broad jump.Instrumen Tesdengantes Lompat Jauh Gaya Jongkok (Jarver, 2005).

\section{HASIL DAN PEMBAHASAN}

\section{Deskripsi Data Tes Awal (pre test) Hasil Lompat Jauh Gaya Jongkok}

Sebelum diberi perlakuan (treatment) berupa latihan standing broad jump, siswa terlebih dahulu melakukan tes awal (pre-test) dengan melakukan lompat 192 | Copyright@HON 
Mirza Awali (2020)

Pengaruh Latihan Standing Broad Jump Terhadap Lompat Jauh Siswa SMP Negeri 2 Lahat

jauh gaya jongkoksebanyak tiga kali dan hasil diambil dari nilai terbesar. Adapun data dari tes awal (pre-test)ini adalah sebagai berikut :

Tabel 2. Data Hasil Pre-Test Lompat Jauh Gaya Jongkok

\begin{tabular}{cc}
\hline Jumlah Nilai & 25.90 \\
\hline Rata-rata & 1.30 \\
Skor Tertinggi & 2.01 \\
Skor Terendah & 1.05 \\
\hline
\end{tabular}

Berdasarkan data pre-teslompat jauh, dapat diketahui bahwa hasil rata-rata tes adalah 1.30.Hasil tes skortertinggi adalah 2.01dan terendah1.05.Untuk lebih jelasnya dapat dilihat pada tabel distribusi dan diagram sebagai berikut:

Tabel 3. Data Distribusi Hasil Pre-TestLompat Jauh Gaya Jongkok

\begin{tabular}{cccc}
\hline No & Nilai & $\mathbf{f}_{\mathbf{a}}$ & $\mathbf{f}_{\mathbf{r}}$ \\
\hline 1 & $1.05-1.24$ & 13 & $65 \%$ \\
2 & $1.25-1.44$ & 2 & $10 \%$ \\
3 & $1.45-1.64$ & 3 & $15 \%$ \\
4 & $1.65-1.84$ & 1 & $5 \%$ \\
5 & $1.85-2.04$ & 1 & $5 \%$ \\
& $\sum$ & $\mathbf{2 0}$ & $\mathbf{1 0 0 \%}$ \\
\hline
\end{tabular}

Berdasarkan tabel data distribusi frekuensi hasil pre-test lompat jauh gaya jongkok, makadapat digambarkan diagram untuk tes awal (pre-test) adalah sebagai berikut:

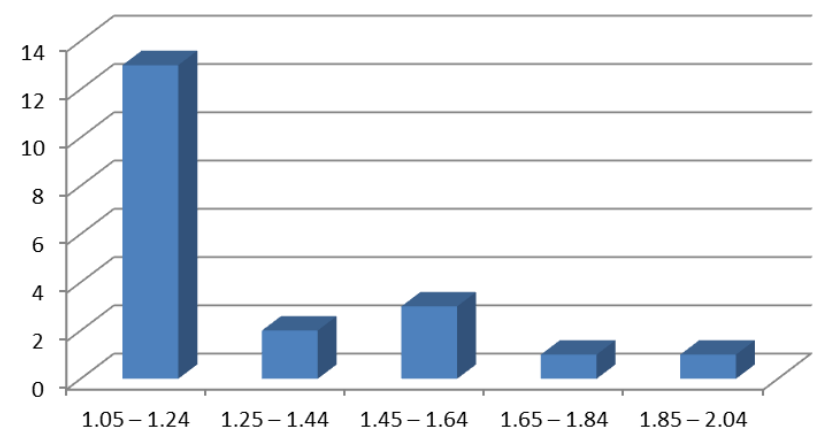

Gambar 1. Diagram Pre-Test Lompat Jauh Gaya Jongkok 
Mirza Awali (2020)

Pengaruh Latihan Standing Broad Jump Terhadap Lompat Jauh Siswa SMP Negeri 2 Lahat

2. Deskripsi Data Tes Akhir (post test) Lompat Jauh Gaya Jongkok

Setelah siswa melakukan tes awal (pre-test) dan diberi perlakuan (treatment) berupa latihan standing long jump, selanjutnya siswa melakukan tes akhir (post-test) yaitu melakukan lompat jauh gaya jongkoksebanyak tiga kali dan hasil diambil dari nilai terbesar. Adapun data dari tes akhir (post-test) ini adalah sebagai berikut:

Tabel 4. Data Hasil Post-TestLompat Jauh Gaya Jongkok

\begin{tabular}{cc}
\hline Jumlah & 36.85 \\
\hline Rata-rata & 1.84 \\
Skor Tertinggi & 2.50 \\
Skor Terendah & 1.20
\end{tabular}

Berdasarkan data post-teslompat jauh, dapat diketahui bahwa hasil ratarata tes adalah 1.84.Hasil tes skortertinggi adalah 2.50dan terendah1.20.Untuk lebih jelasnya dapat dilihat pada tabel distribusi dan diagram sebagai berikut:

Tabel 5.Data Distribusi Hasil Post-TestLompat Jauh Gaya Jongkok

\begin{tabular}{cccc}
\hline No & Nilai & $\mathbf{f}_{\mathbf{a}}$ & $\mathbf{f}_{\mathbf{r}}$ \\
\hline 1 & $1.20-1.46$ & 3 & $15 \%$ \\
2 & $1.47-1.73$ & 6 & $30 \%$ \\
3 & $1.74-2.00$ & 5 & $25 \%$ \\
4 & $2.01-2.27$ & 4 & $20 \%$ \\
5 & $2.28-2.54$ & 2 & $10 \%$ \\
& $\sum$ & $\mathbf{2 0}$ & $\mathbf{1 0 0 \%}$ \\
\hline
\end{tabular}

Berdasarkan tabel data distribusi frekuensi hasil post-test lompat jauh gaya jongkok, maka dapat digambarkan diagram untuk tes akhir (post-test) adalah sebagai berikut:

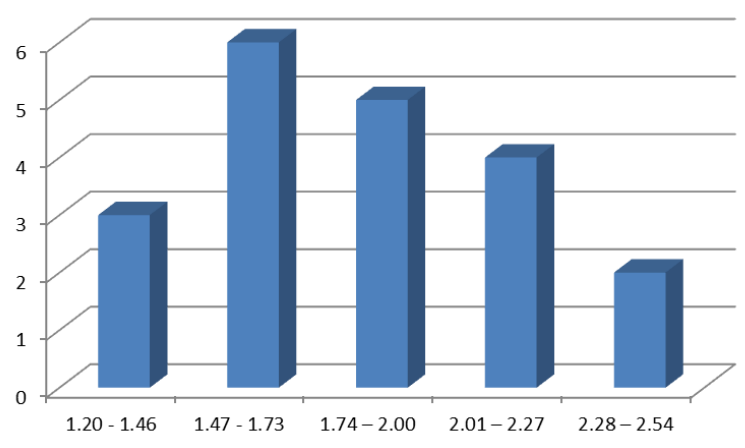


Pengaruh Latihan Standing Broad Jump Terhadap Lompat Jauh Siswa SMP Negeri 2 Lahat

Gambar 2. Diagram Post-Test Lompat Jauh Gaya Jongkok

Uji normalitas di ujikan pada masing-masing data penelitian yaitutingkat kesegaran jasmani.Uji normalitas dilakukan menggunakan uji liliefors.Dalam uji ini akan menguji hipotesis: sampel berasal dari populasiberdistribusi normal. Untuk menerima atau menolak hipotesis denganmembandingkan harga Signifikan dengan harga 0,05. Kriterianya adalahmenerima hipotesis apabila angka signifikan lebih besar dari 0,05 ( $\mathrm{Sig}>0,05)$.

Hasil analisis uji normalitas sebaran data masing-masing variabel disajikan dalam tabel berikut ini:

Tabel 6.Uji Normalitas Data

\begin{tabular}{cccccc}
\hline No & Variabel & $\mathrm{n}$ & $\mathrm{L}_{\mathrm{o}}$ & $\mathrm{L}_{\text {tabel }}$ & Distribusi \\
\hline 1 & Pre Test Tingkat Kebugaran Jasmani & 20 & 0,182 & 0,190 & Normal \\
2 & Post Test Tingkat Kebugaran Jasmani & 20 & 0,086 & 0,190 & Normal \\
\hline
\end{tabular}

Berdasarkan tabel di atas dapat menunjukan bahwa hasil pengujian untuk pengukuranPre Test Tingkat Kebugaran Jasmani skor Lo $=0,182$ danL tabel diperoleh $=0,190$. Data dikatakan berdistribusi normal apabila $\mathrm{L}_{\text {hitung }}<\mathrm{L}_{\text {tabel. }}$. Sehingga disimpulkan bahwa skorPre Test Tingkat Kebugaran Jasmani berdistribusi normal. Hasil Post Test Tingkat Kebugaran Jasmani skor Lo = 0,086 dan $\mathrm{L}_{\text {tabel }}$ diperoleh $=0,190$. Data dikatakan berdistribusi normal apabila $\mathrm{L}_{\text {hitung }}<\mathrm{L}_{\text {tabel, }}$ sehingga disimpulkan bahwa Hasil Post Test Tingkat Kebugaran Jasmanidi dapatkan hasil berdistribusi normal.

Tabel 7. Data Hasil Pretest dan Posttest

\begin{tabular}{|c|c|c|c|c|c|c|c|}
\hline \multirow{2}{*}{ No } & \multirow{2}{*}{ Nama Siswa } & \multicolumn{2}{|c|}{ Jarak } & \multirow{2}{*}{$\mathrm{d}$} & \multirow{2}{*}{$d^{2}$} & \multirow{2}{*}{$\begin{array}{c}\mathrm{Xd} \\
\text { (d-Md) }\end{array}$} & \multirow{2}{*}{$\mathrm{X} d^{2}$} \\
\hline & & Pretest & Posttest & & & & \\
\hline 1 & Resp. 1 & 1.22 & 2.22 & 1.00 & 1.00 & 0.453 & 0.2048 \\
\hline \multirow[t]{2}{*}{20} & Resp. 20 & 1.09 & 1.63 & 0.54 & 0.29 & -0.0075 & 0.0001 \\
\hline & Jumlah & 25.90 & 36.85 & 10.95 & 8.42 & & 2.4224 \\
\hline
\end{tabular}


Perhitungan di atas dapat disimpulkan $t_{\text {hitung }}>t_{\text {tabel }}$ atau 6,86>1,73, maka tolak Ho dan terima Ha. Dengan demikian dapat disimpulkan bahwa ada pengaruh latihan standing broad jump terhadap hasil lompat jauh gaya jongkok pada siswa putra kelas VIII SMP Negeri 2 Lahat.

\section{Pembahasan}

Berdasarkan hasil penelitian yang dilaksanakan, terdapat pengaruh yang signifikan latihan standing board jump terhadap hasil lompat jauh gaya jongkokdi SMP Negeri 2 Lahat. Hal tersebut dapat dilihat dari hasil lompatanyang diperoleh dari tes akhir (post-test) lebih besar dari hasil lompatanawal pada saat tes awal (pre-test). Kenyataan ini dapat dilihat dari masing-masing nilai rata-rata tes. Untuk nilai rata-rata tes awal (pre-test) yaitu 1,30 dengan standar deviasi 0,28 sedangkan untuk nilai rata-rata tes akhir (post-test) yaitu 1,84 dengan standar deviasi 0,37 .

Selanjutnya untuk melihat atau mengetahui seberapa besar pengaruh latihan standing board jumpterhadap hasil lompat jauh gaya jongkoksiswa dilakukan uji signifikan dan diperoleh nilai harga $t_{\text {hitung }}$ sebesar 6,86 dan $t_{\text {tabel }}$ sebesar 1,73. Jadi $t_{\text {hitung }}>t_{\text {tabel }}$, dengan demikian $H_{a}$ diterima dan $H_{o}$ ditolak yang artinya terdapat pengaruh yang signifikan latihan standing board jumpterhadap hasil lompat jauh gaya jongkok di SMP Negeri 2 Lahat.

Dalam kajian fisiologi olahraga menjelaskan bahwa latihan akanmenyebabkan terjadinya perubahan-perubahan anatomis, kimiawi, danfisiologis. latihan yang berasal dari kata training adalah suatu proses penyempurnaan kemampuan berolahraga yang berisikan materi teori dan praktik, menggunakan metode dan aturan pelaksanaan dengan pendekatan ilmiah, memakai prinsip-prinsip latihan yang terencana dan teratur, sehingga tujuan latihan dapat tercapai tepat pada waktunya.

Temuan dalam penelitian ini menjelaskan bahwa atlet yang diberi latihan standing broad jump akan mampu melakukam lompat jauh gaya jongkok dengan baik dan optimal. Dengan demikian dapat dikatakan bahwa lompat jauh terkait 
dengan program latihan standing broad jump yang dilakukan para siswa putra kelas VIII di SMP Negeri 2 Lahat. Disamping itu, hasil penelitian ini juga menunjukkan bahwa latihan standing broad jump penting dilakukan dan ditingkatkan oleh setiap siswa dalam meningkatkan kemampuan lompat jauh gaya jongkok.

Dengan demikian maka dapat dijelaskan pentingnya latihan standing broad jump yang baik sehingga dapat meningkaitak kemampuan lompat jauh gaya jongkok, kemudian latihan standing broad jump juga memiliki peran dalam jauhnya lompatan pada lompat jauh gaya jongkok, artinya semakin meningkat kemampuan standing broad jump maka semakin baik jauhlompatan lompat jauh gaya jongkok. Hal tersebut juga dijelaskan pada hasil perlakuan yang diberikan yang mana metode latihan standing broad jump dapat meningkatkan hasil kemampuan lompat jauh gaya jongkok.

\section{KESIMPULAN}

Berdasarkan hasil penelitian yang telah dilakukan terhadap siswa kelas VIIISMP Negeri 2Lahat, tentang pengaruh latihan standing broad jump terhadap hasil belajar lompat jauh gaya jongkok sebanyak 20 siswa diperoleh hasil pada uji normalitas data bahwa semua data berdistribusi normal, baik pre-test maupun post-test. Kemudian pada uji hipotesis diperoleh hasil $t_{\text {hitung }}$ adalah 6,86 sedangkan $t_{\text {tabel }}$ adalah 1,73 Sudah menjadi ketentuan bahwa apabila $t_{\text {hitung }}>t_{\text {tabel }}$, maka $H_{a}$ (Hipotesis diterima) dan sebaliknya apabila $t_{\text {hitung }}<t_{\text {tabel }}, H_{o}$ (Hipotesis ditolak), maka dapat disimpulkan bahwa latihan standing broad jump berpengaruh terhadap hasil lompat jauh gaya jongkok pada siswa kelas VIII SMP Negeri 2 Lahat.

\section{DAFTAR PUSTAKA}

Arikunto, S. (2010). Prosedur Penelitian Suatu Pendekatan Praktik. 2010. Jakarta: Rineka Cipta.

Husdarta, H. J. S. (2009). Manajemen pendidikan jasmani. Bandung: Alfabeta. 
Pengaruh Latihan Standing Broad Jump Terhadap Lompat Jauh Siswa SMP Negeri 2 Lahat

Jarver, J. (2005). Belajar dan berlatih atletik. Bandung: CV. Pionir Jaya.

Kurnia, M. (2018). Pengaruh Latihan Lari Sprint 50 Meter Terhadap Hasil Lompat Jauh Siswa Kelas X Sma Negeri 11 Palembang. Halaman Olahraga Nusantara (Jurnal Ilmu Keolahragaan), 1(2), 133-148.

Kurniawan, F. (2012). Buku pintar pengetahuan olahraga. Jakarta: Laskar Aksara.

Lengkana, A. S. (2018). Kontribusi Belajar Lompat Katak Dan Engklek Terhadap Penampilan Teknik Lompat Jauh Gaya Jongkok Di Sekolah Dasar. Halaman Olahraga Nusantara (Jurnal Ilmu Keolahragaan), 1(2), 149159.

Rahmani, M. (2014). Buku super lengkap olahraga. Jakarta: Dunia Cerdas.

Sugarwanto, S., \& Okilanda, A. (2020). Pengaruh Latihan Single Leg Hops Terhadap Hasil Lompat Jangkit Siswa Smp 1 Sungai Lilin. Kinestetik: Jurnal Ilmiah Pendidikan Jasmani, 4(1), 85-89.

Sugiyono. (2008). Metode penelitian pendidikan:(pendekatan kuantitatif, kualitatif dan $R \& D)$. Alfabeta.

Suherman, A., Saputra, Y. M., \& Hendrayana, Y. (2001). Pembelajaran Atletik: Pendekatan Permainan dan Kompetisi. Jakarta. Dirjen Dikdasmen Dan Direktorat Jenderal Olahraga, 133.

Sukirno, S., \& Pratama, R. R. (2018). Pengembangan Model Pembelajaran Atletik Berbasis Permainan Di Sekolah Dasar. Altius: Jurnal Ilmu Olahraga Dan Kesehatan, 7(2).

Wiarto, G. (2013). Atletik. Yogyakarta: Graha Ilmu.

Winarno, M. E. (2007). Research Methodology in Physical Education. Malang: Faculty of Education, Malang State University. 